\title{
Why You Should Have a Lawyer on Your Startup Board
}

\section{Dustin Slade (Ibex Aegis)}

KEYWORDS: Entrepreneurship, Leadership, Legal, Startups.

In 1979, Personal Software began selling Visicalc, the first personal computer spreadsheet. Visicalc was so compelling, people bought Apple II computers just so they could use Visicalc, making it the first "killer app" in history. Visicalc also single-handedly turned the personal computer from a hobby for computer geeks into a business tool. Despite this momentum, Visicalc was displaced by Lotus 1-2-3 almost immediately after Lotus's release in 1983. In hindsight, if Visicalc had sought a patent in its first year, it would likely today be a household name instead of Microsoft Excel.

A significant problem for every entrepreneur is traversing a legal minefield where missteps are unforgiving and often fatal. But attorneys who can anticipate and steer around these minefields are expensive, forcing most startups to keep legal services to a minimum. One possible way to help address this conundrum is to appoint a lawyer to your board, and compensate him or her with the same equity package you offer other board members.

A lawyer serving on your board will not only help your company avoid mistakes but can also help identify positive opportunities and make connections with other lawyers who may be key to your success.

\section{Avoiding Costly Mistakes}

A startup faces countless legal pitfalls before becoming successful. For example, say you have a falling-out with a minority shareholder who repeatedly engaged in unethical practices. You have frozen her out of day-today operations, but she has sworn she is going to get even with you. One day, she sends you an abusive letter accusing you of wrongdoing and demanding to see corporate books and records. You should peremptorily deny her request, right? Wrong. Denying this request is in violation of corporate law and exposes you to costly litigation, which may include an award of attorneys' fees and a hefty statutory penalty. With a lawyer on your board, a quick phone call in delicate situations like these can help avoid months or even years of heartburn.

Another example: your co-founder, currently serving on the board, asks you and the other board member to release him from a non-competition agreement. He is a close personal friend to you both, so you feel a lot of personal pressure to give in to his demands. Having a lawyer on your board would help you see this is an extremely dangerous situation, as letting him out of her non-compete would likely be a breach of your fiduciary duty.

Having a lawyer on your board can also help avoid costly human resource mistakes. For example, many entrepreneurs are not aware that alcoholics and currently non-using illicit drug addicts are protected by the Americans with Disabilities Act. Making critical decisions with a lawyer's input can help you circumvent these and countless other landmines.

Perhaps the biggest single reason to include a lawyer on your board is to protect you from running afoul of complex state and federal securities laws, the violation of which can lead to not only hefty civil liability but also jail time. Even attorneys who are not experienced in securities law should know enough to identify delicate terrain requiring expert advice and will know others who are qualified. Lawyer-directors can also review marketing materials and private placement memos and are in a better position than outside counsel to spot potentially misleading statements -- an absolute essential in avoiding securities liability.

If the lawyer you choose to include on your board is a litigator, you have gained an immensely valuable trove of experience of what can go wrong in business deals and how to position your company to win in litigation in case things do go wrong. However, because litigators see so many deals enter worst-case-scenario, at times they may need to be asked if their views are being distorted by their litigation experience. A good advisor will appreciate your raising this issue and respect you all the more for it.

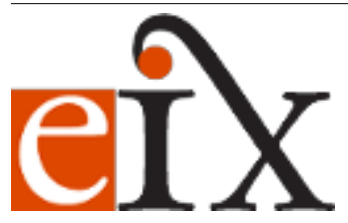

Copyright ( $) 2019$ The Authors. Entrepreneur \& Innovation Exchange is published at EIX.org. This is an open access article under the terms of the Creative Commons Attribution-NoDerivs License, which permits use and distribution in any medium, provided the original work is properly cited and no modifications or adaptations are made. View EIX.org Authorship Terms at https://eix.org/terms 


\section{Identifying Opportunities}

The right lawyer for your board is someone who not only can help steer your company away from danger but who also can recognize and help you take advantage of potential opportunities. Any lawyers who have been in private practice for an extended period of time are themselves entrepreneurs, navigating many of your company's very same issues, including operations management, customer acquisition and relations, branding, and public relations. The instincts and insights they have gained through this aspect of their legal practice will harmonize well with your goals and action plans. For example, lawyers usually have an ability to read between the lines and respond to subtle cues that can make them an ideal addition at key, outwardengaging meetings.

Additionally, lawyers are often avid newspaper readers, keeping a pulse on local gossip, litigation activity, and community perception of their clients. Lawyers thus often know which businesses are doing well, which are facing significant challenges, and where your company might have unique opportunities.

Lawyers also know subtle steps that can be taken to help you gain an advantage in all sorts of legal situations. For example, though you may spend slightly more on attorneys' fees by being the one to draw up the first draft of a contract, doing so helps you set the baseline of important terms. A lawyer will know that you want to have a venue clause, choice-of-law clause, and perhaps attorneys' fees and arbitration provisions in all your contracts. A lawyer can help you make choice-ofentity determinations, explain some basic tax consequences of these choices, and help remind you to do such things as file Section 83(b) elections to avoid negative tax consequences regarding the shares issued to founders and early hires.

It is important that the lawyer you select is one who will both flag dangerous issues and identify positive opportunities. If, in 1979 or early 1980, Personal Software had been advised by an attorney who saw patenting Visicalc as an opening to challenge the USPTO's outdated rule against patentability of software, Visicalc almost certainly would have reaped the benefits of the Supreme Court's 1981 ruling in Diamond v. Diehr, which overturned the USPTO and granted a software patent that had been filed in 1975. Thus, Personal Software would have had a formidable moat protecting its market share from the competitors who made Visicalc obsolete.

\section{Connections with Other Lawyers}

When the need arises to engage corporate counsel, having a director who is an insider to the legal community is invaluable. Lawyers know their fellow lawyers. They will have informed opinions regarding not only the competence of other attorneys but also their integrity. They know other lawyers' personalities and will have a sense of who would be a good fit for you and your company. They may also know which attorneys will most likely be able to practice within your company's budget constraints.

Even when unfamiliar with a prospective attorney, a lawyer is specially equipped to read between the lines when scouting an unfamiliar lawyer. For example, I once worked with a company that had been using a transactional attorney whose web page stated almost three quarters of his work was devoted to litigation. This suggested to me that while he was perhaps minimally qualified to draft basic documents, he was not a transactional expert. After catching serious flaws in his subsequent work, I was able to instead connect the company to an extremely competent transactional attorney whose sole focus was advising start-ups.

\section{Choosing an Attorney For Your Board}

All lawyers are familiar with contingency fees, so offering them an equity package as compensation for sitting on a board will immediately resonate with their professional experience. As with any contingency case, your target will balance the risk of failure with the potential monetary reward. If a lawyer accepts your offer, he or she probably thinks you and your company have promise.

Though you should make an offer to anyone you think is an ideal fit for your board, consider someone who understands entrepreneurship and who has perhaps had other entrepreneurs as clients and connections. You will also most likely have success targeting a lawyer who is actively seeking new clients but still seasoned enough to have valuable connections and extensive professional experience. Such a lawyer will likely see your offer as not only an opportunity to get equity in a promising company, but also an avenue to make connections that could lead to more business. Lawyers won't survive if they don't have work, and, 
even at large international firms, promotion is often dependent on bringing in new clientele.

During the interview, ask candidates about their experience. The more it dovetails with your company's needs and goals, the better fit he or she is likely to be. However, that should not be your only consideration. As with filling any position, your conversation should be aimed at getting a sense of whether the candidate is likeable, conscientious and caring. This type of lawyerdirector will be more likely to care about your company; to work hard to make it a success; and to have the respect and admiration of past connections who may also be able to help in the future.

It is important to note that the lawyer you select will likely serve only on the condition that an attorney-client relationship not be established, thereby avoiding potential conflicts of interest. Despite the fact that attorney-client privilege does not apply and that other aspects of the relationship will be different, your attorney -- like your other directors -- will have the same fiduciary duties that require her to act as though your company's interests were her own. The right lawyer/director will be doing that anyway.

This article is not intended as legal advice and should not be considered as such. 